\title{
Development of diet cereal bar sweetened with stevia leaves pre-treated with ethanol
}

\author{
Sandra Beserra da SILVA ${ }^{1 \star}$ (D), Maysa Ariane FORMIGONI ${ }^{1}$, Maria Rosa ZORZENON ${ }^{1}$, Paula Gimenez MILANI ${ }^{2}$, \\ Antonio Sérgio DACOME², Flávio Augusto Vicente SEIXAS³, Silvio Claúdio da COSTA²
}

\begin{abstract}
The objective of this work was to perform the ethanolic pretreatment of stevia leaves from the plant Stevia UEM-13 line and to characterize its physical-chemical properties aiming its use as a sweetener in the development of a diet cereal bar. The same formulation of the cereal bar with stevia leaves without pretreatment was elaborated for comparative purposes. The following ingredients were used in the preparation of the produtc: fine oat flakes, no sugar granola, cranberry, dehydrated apricots, water, gum acacia and stevia leaf pretreated (F1) and without treatment (F2). According to the results, the diet cereal bars presented significant amounts of crude fiber, protein and antioxidant activity. The product was microbiologically safe for human consumption, reporting lower microbiological valuesthan those foreseen by official regulation. The overall sensory evaluation indicates that the two formulations did not present statistically significant differences regarding the analyzed attributes, being the averages between "liked very much" and "moderately liked". However, considering the group of cereal bars consumers, the formulation sweetened with pretreated leafs (F1) was found more than twice the acceptance regarding to the formulation sweetened with the leaf in natura (F2). These results demonstrate a viable option of a diet food product naturally sweetened.
\end{abstract}

Keywords: Stevia rebaudiana; cereal bar; natural sweetener; diet food.

Practical Application: Sugar substitution by natural ingredient - stevia leaf pretreated in diet cereal bar.

\section{Introduction}

The Stevia rebaudiana (Bertoni) is plant of the Asteraceae family, which presents in its leaves, stems and flowers, the steviol glycosides with sweetness power ranging between 300 and 450 times greater than sucrose, acting at the limit of the sweet taste perception (Lemus-Mondaca et al., 2012). Among the glycosides of steviol, the most prominents are the rebaudiosides - $\mathrm{A}$ and $\mathrm{C}$, and also the stevioside, the latter being classified according to its sweet sensorial profile (Wölwer-Rieck, 2012). The stevioside present in the stevia leaf has as characteristic a residual bitter taste in its composition, limiting its use in the food industry, as well as the presence of other phytochemical compounds (Formigoni et al., 2018).

Studies aiming sweetener extractions have been carried out with the intention of minimizing or retarding the characteristic residual flavor present in the stevia leaf in natura (Formigoni et al., 2018; Das et al., 2015; Jentzer et al., 2015). Formigoni et al. (2018), have recently reported an ethanolic pretreatment of stevia leaves, which they point out as an innovative approach, where the process selectively removes phenolic compounds and flavonoids that contribute significantly to the bitter taste in the final product.

Currently, most of the dietary products marketed are developed with the addition of synthetic sweeteners, where the main source is sucralose. However, they have certain drawbacks such as: they are not totally effective in sweetening nor able to provide health benefits (Gasmalla et al., 2017; Kalicka et al., 2019). The continuous use of these sweeteners can lead to an increase in weight (obesity) and have been targets of several criticisms due to its supposed neurological effect (Honorato et al., 2013; Kalicka et al., 2019). There are reports that the sucralose sweetener can generate toxic compounds known as chloropropane, as well other related compounds, when exposed to high temperatures (Yildiz-Ozturk et al., 2015).

Due to the constant concern of people about the health risks of high sucrose intake, such as diabetes, obesity and cardiovascular disease, it is a challenge for the food industry to develop new formulations of non-sweetener-based products, which are endowed of characteristics and taste close to sucrose (Yildiz-Ozturk et al., 2015; Edwards et al., 2016; Lobete et al., 2017; Carvalho et al., 2019; Kalicka et al., 2019). According to Mooradian et al. (2017), limiting or reducing the consumption of any kind of caloric or artificial sweetener is of utmost importance for human health. They also emphasize that natural sweeteners have favorable effects on body weight and metabolism when replaced by sucrose.

This growing concern for a healthy diet puts some products and ingredients as a top priority in the development of new foods (Ciulu et al., 2017; Miele et al., 2017; Carvalho et al., 2019). 
In order to serve the market segment of special foods, the diet cereal bars have gained prominence due to their several health benefits (Srebernich et al., 2011), besides providing practicality of consumption. There are several diet cereal bars sweetened by synthetic sweeteners in the consumer market. However, they present certain drawbacks such as residual bitter taste, which limitates the intake of this kind of product by the consumers who do not follow diets with artificial sweeteners.

Due to these limitations, the food industry must constantly maintain the principle of innovation and product development that anticipates certain needs and demands of the market. In this sense, cereal bars with the addition of pre-treated stevia leaf and natural ingredients that present functional, nutritional and sensorial properties, appear in the market to serve consumers who are adepts and are restrictions in the intake sucrose or artificial sweeteners. It is also considered that being an innovation in the field of food products, this food is interesting on a nutritional, social, economic and scientific point of view.

Therefore, the objective of this work was to obtain the stevia leaf pre-treated with ethanol according to the methodology of Formigoni et al. (2018), and evaluate them as to the chemical properties before and after the treatment, as well as to use them in formulations of cereal bars. Such formulations will be evaluated by physical-chemical centesimal methods, antioxidant activity, microbiological security as well as sensorial evaluations, aiming to contribute to the development of a food formulation with direct technological application, by using pre-treated stevia leaves as a sweetener alternative for innovative products.

\section{Materials and methods}

\subsection{Materials}

In order to carry out this work, stevia leaves of the seminal variety UEM-13, cultivated at NEPRON (Núcleo de Produtos Naturais da Universidade Estadual de Maringá) were harvested at the stage of maximum vegetative growth (55-60 days). Stevia shrubs were previously oven dried with forced air circulation at $60{ }^{\circ} \mathrm{C}$ until moisture content was below $10 \%$. The leaves were manually separated from the stalks and branches and then, kept in identified sterile plastic bags. The solvents and reagents used were of analytical grade (P.A.) with purity $>99.5 \%$.

\subsection{Ethanolic pre-treatment and preparation of the aqueous extract from leaves (tea)}

The ethanolic treatment of the Stevia rebaudiana leaves was performed by means of ion exchange chromatography column according to the methodology described by Formigoni et al. (2018). For the preparation of the extracts, $2 \mathrm{~g}$ of pre-treated or in natura leaves (UEM-13) were weighed into a $250 \mathrm{~mL}$ beaker, previously ground. A volume of $100 \mathrm{~mL}$ of distilled water was added, then boiled $\left(100{ }^{\circ} \mathrm{C}\right)$ for five minutes under constant stirring. Finally, the mixture was filtered on filter paper under vacuum. The retained leaves were transferred back into the beaker with the addition of $100 \mathrm{~mL}$ of water, for further boiling and filtration. This procedure was repeated again, however, with the addition of $50 \mathrm{~mL}$ of water in the retained leaves. Then, the volume of the aqueous filtrate was adjusted to $250 \mathrm{~mL}$ with distilled water and, finally, the resulting extract was filled into $100 \mathrm{~mL}$ amber flasks and immediately analyzed by HPLC (Gilson, model 307). For the accomplishment of the physicochemical analyzes the aqueous extracts and the dry leaves of the pre-treated and in natura samples were used.

\subsection{Determination of glycosides from aqueous extract of the leaves}

Total glycosides, especially stevioside and rebaudiosides A and $\mathrm{C}$, were determined by high performance liquid chromatography (HPLC). For the analysis of the leaves, $10 \mathrm{~mL}$ of the tea sample (aqueous extract) was concentrated in a rotary evaporator and the product was resuspended in $2.0 \mathrm{~mL}$ of deionized water and $8.0 \mathrm{~mL}$ of acetonitrile (J.T. Baker HPLC grade $>99.9 \%$ ), used as mobile phase, filtered 3 times in $0.45 \mu \mathrm{m}$ syringe filter, and analyzed by liquid chromatograph (Gilson, model 307), coupled to a $S: 32$ refractive index detector, with a $5 \mu \mathrm{m} \mathrm{NH}_{2}$ column with dimensions of $125 \times 4.6 \mathrm{~mm}$.

\subsection{Centesimal and physicochemical characterization of leaves}

The determination of total moisture, ashes, protein, lipids and total fiber content were performed according to the methodology proposed by the Instituto Adolf Lutz (2004).

The concentration of total phenolic compounds was determined according to the method described by Singleton et al. (1999) with modifications, where the absorbance was measured at $760 \mathrm{~nm}$ and expressed as gallic acid equivalents (EAG). For the quantification of total flavonoids the method described by Zhishen et al. (1999) was used with modifications, where the absorbance was measured at $510 \mathrm{~nm}$. Data were expressed as routine equivalents. For the determination of chlorophylls $\mathrm{A}$ and $\mathrm{B}$, the method described by Arnon (1949) was used with modifications, where the absorbances were measured at wavelengths 645 and $663 \mathrm{~nm}$, being expressed as $\mathrm{mg} \times 100 \mathrm{~g}^{-1}$. All analyzes were performed in duplicate to obtain means and standard deviation.

\subsection{Development of cereal bar}

The formulations were prepared in the Laboratory of Vegetal Products at the State University of Maringá (UEM), campus of Umuarama - PR, and the ingredients were purchased in local markets. The formulations of the cereal bars were expressed as a percentage of the ingredients as: oat flake (18\%), no sugar granola (29\%), dehydrated apricot (9\%), dehydrated cranberry (9\%), stevia leaves (1.8\%), acacia gum $(8.2 \%)$ and water $(25 \%)$. The binder solution (acacia gum, water and stevia leaves macerated) was heated to $105^{\circ} \mathrm{C}$ by $3 \mathrm{~min}$. After this time, the dry ingredients were slowly incorporated into this solution still hot, under continuous agitation in a cooking pot. The mixture was then spread with the aid of a cylinder until it reached an average thickness of $1 \mathrm{~cm}$. The following formulations were prepared: F1 with pretreated stevia leaves and F2 with stevia leaves in natura. The samples were packed in packs made with pvc film for further analysis. 


\subsection{Microbiological analyses}

Microbiological analyzes were performed at the Laboratory of Food Microbiology of the State University of Maringá (UEM), Campus of Umuarama - PR, according to the methodology proposed by Silva et al. (2001), and the reccomendations from RDC no 12/2001 of ANVISA (Brasil, 2001) for cereals, where Bacillus cereus, Salmonella spp, total yeast and mold counts were evaluated, as well as coliforms $45^{\circ} \mathrm{C}$.

\subsection{Sensory evaluations}

The sensory evaluations were carried out at the Sensorial Analysis Laboratories (DTC/UEM), in individual booths under white light after the approval of the project by the Ethics Committee of UEM (CAAE 18718013.3.0000.0104). To verify the acceptability and preference of the panelists, a 9-point hedonic scale was adopted $(1=$ extremely disagreeable) $(9=$ extremely liked). The evaluated attributes were the general appearance, aroma, flavor and texture. In addition, the intent to purchase the product according to the scale $(5=$ definitely buy; $1=$ definitely would not buy) has been verified. The characterization of the sensory team, regarding the consumption of diets products, was also evaluated. The sensory panel consisted of 100 untrained individuals of both genders, aged 15 to 55 years. The panelists were previously instructed on how to complete the evaluation form and conduct the analysis. Samples with $\sim 2 \mathrm{~g}$ were served to panelists at random in disposable white cups, encoded with random numbers plus evaluation forms, and free consent term. The results were evaluated by means of the Tukey and Anova tests, with significance level of $5 \%$.

\section{Results and discussion}

\subsection{Physical-chemical characterization of stevia leaves}

The results from the analysis of the centesimal composition, as well as other phytochemical constituents of Stevia rebaudiana leaves, with and without ethanolic treatment, are shown in Table 1.

There was a significant decrease $(\mathrm{p}>0.05)$ in the yields of twelve constituents among fifteen analyzed, regarding the pretreated leaves compared to in natura. This result was already expected since the ethanolic extraction may drag of some compounds present in the leaves. This can be explained by the fact that ethanol is an amphipathic solvent capable of dissolving a lot of polar and nonpolar compounds (Formigoni et al., 2018).

Regarding total glycosides, steviosides and rebaudiosides A and C, no significant variations $(\mathrm{p}<0.05)$ were observed between the two groups. Significant variations $(p>0.05)$ in the comparison of the parameters proteins, lipids, moisture, chlorophylls A and B, total chlorophyll and phenolic compounds were observed between the two treatments. These results are in agreement with previous analyzes reported (Formigoni et al., 2018).

In the paper of Martins et al. (2016), yields of $2.15 \%$ is reported for the compound rebaudioside A and, $1.27 \%$ for the stevioside, both extracted with ethanol solvent by the maceration process. In our work, although the solvent was the same (ethanol), the extraction process used was ion exchange column and, in this case, the yields for extraction of rebaudioside A and stevioside were 4.9 and $3.7\left(\mathrm{~g} \times 100 \mathrm{~g}^{-1}\right)$ respectively, demonstrating that the ethanolic pretreatment performed on stevia leaves by column is advantageously feasible. Amounts very similar to ours has also been obtained by the same methodology and reported in the literature (Formigoni et al., 2018).

The flavonoid levels measured for the two treatments were statistically the same $(\mathrm{p}>0.05)$, but higher than the value of $15.64 \mu \mathrm{g} \times \mathrm{EQ} \mathrm{g}^{-1}$ reported in literature (Kim et al., 2011) obtained from the aqueous extract of stevia leaves. The same literature reports the value of $130 \mu \mathrm{g} \times \mathrm{EQ} \mathrm{g}^{-1}$ for phenolic compounds, which is below the reported in this work.

Regarding anthocyanins, although the value measured in the pretreated leaf is significantly lower than that of the in natura leaf $(\mathrm{p}>0.05)$, they do not represent an expressive amount compared to other foods rich in these compounds (Texeira et al., 2008). This is justified by the fact that this pigment is more frequently found in significant amounts in the fruits compared to the leaves of the plants (Cavalcanti et al., 2011).

Considering the contents of phenolic compounds and flavonoids, the leaves pretreated with ethanol did not significantly lose their antioxidant potential, thus being able to contribute with the functional properties of the food sweetened with these leaves.

\subsection{Centesimal composition and other phytochemical constituents of the cereal bar}

The formulation of the cereal bar with apricot was an innovative choice, because, to date there are no formulations of this product with this fruit in the Brazilian market. In addition, apricot has interesting nutraceutical properties. It provides protection against radiation and has cardiorespiratory activity in vivo which is associated with its phenolic antioxidant content (Parlakpinar et al., 2009). In addition to polyphenols, apricot is also a rich source of carotenoids and vitamin C (Hegedüs et al.,

Table 1. Centesimal composition and other phytochemical constituents of Stevia rebaudiana with and without ethanolic treatment.

\begin{tabular}{|c|c|c|}
\hline Parameter & Untreated leaf & $\begin{array}{l}\text { Leaf with } \\
\text { treatmen }\end{array}$ \\
\hline Total glycoside $\left(\mathrm{g} \times 100 \mathrm{~g}^{-1}\right)$ & 10.9 & 10.3 \\
\hline Stevioside $\left(\mathrm{g} \times 100 \mathrm{~g}^{-1}\right)$ & 4.0 & 3.7 \\
\hline Rebaudioside C $\left(\mathrm{g} \times 100 \mathrm{~g}^{-1}\right)$ & 1.8 & 1.7 \\
\hline Rebaudioside A $\left(\mathrm{g} \times 100 \mathrm{~g}^{-1}\right)$ & 5.1 & 4.9 \\
\hline Proteins $\left(\mathrm{g} \times 100 \mathrm{~g}^{-1}\right)$ & $20.5^{\mathrm{a}} \pm 0.16$ & $19.6^{\mathrm{b}} \pm 0.12$ \\
\hline Lipids $\left(\mathrm{g} \times 100 \mathrm{~g}^{-1}\right)$ & $2.9^{\mathrm{a}} \pm 0.12$ & $1.3^{\mathrm{b}} \pm 0.10$ \\
\hline Ashes $\left(\mathrm{g} \times 100 \mathrm{~g}^{-1}\right)$ & $10.0^{\mathrm{a}} \pm 0.04$ & $10.7^{\mathrm{a}} \pm 0.42$ \\
\hline Fibers $\left(\mathrm{g} \times 100 \mathrm{~g}^{-1}\right)$ & $5.4^{\mathrm{a}} \pm 0.29$ & $7.6^{\mathrm{b}} \pm 0.39$ \\
\hline Moisture $\left(\mathrm{g} \times 100 \mathrm{~g}^{-1}\right)$ & $6.6^{\mathrm{a}} \pm 0.02$ & $5.5^{\mathrm{b}} \pm 0.05$ \\
\hline Chlorophyll A $\left(\mathrm{mg} \times 100 \mathrm{~g}^{-1}\right)$ & $1.3^{\mathrm{a}} \pm 0.02$ & $0.9^{b} \pm 0.00$ \\
\hline Chlorophyll B $\left(\mathrm{mg} \times 100 \mathrm{~g}^{-1}\right)$ & $1.7^{\mathrm{a}} \pm 0.03$ & $1.5^{\mathrm{b}} \pm 0.00$ \\
\hline Total chlorophyll $\left(\mathrm{mg} \times 100 \mathrm{~g}^{-1}\right)$ & $3.0^{\mathrm{a}} \pm 0.02$ & $2.4^{\mathrm{b}} \pm 0.00$ \\
\hline Anthocyanins $\left(\mu \mathrm{g} \times 100 \mathrm{~g}^{-1}\right)$ & $0.5^{\mathrm{a}} \pm 0.01$ & $0.4^{\mathrm{b}} \pm 0.00$ \\
\hline Phenolic compounds $\left(\mathrm{mg} \times \mathrm{EAG} \mathrm{g}^{-1}\right)^{\star}$ & $4.8^{\mathrm{a}} \pm 0.00$ & $4.3^{\mathrm{a}} \pm 0.00$ \\
\hline Flavonoids $\left(\mathrm{mg} \times \mathrm{EQ} \mathrm{g}^{-1}\right)^{\star}$ & $1.2^{\mathrm{a}} \pm 0.01$ & $1.2^{\mathrm{a}} \pm 0.02$ \\
\hline
\end{tabular}


2011), characteristics that add functional value to the developing cereal bar.

Another component that added nutritional value to the product under development was cranberry. Because it contains low sugar level and high levels of organic acids, mainly citric acid (Vitamin C), which confers most of its acidity. In addition, cranberry is a fruit with antioxidant properties, rich in flavonoids, anthocyanins, pro-anthocyanins, phenolic acids and vitamins. According to its nutraceutical properties, the cranberry fruit is beneficial to human health in combating infections at urinary tract, as well gastrointestinal, cardiovascular and anti-inflammatory diseases (Nowacka et al., 2018).

Table 2 presents the mean values of the physico-chemical analyzes of the two formulations of cereal bars sweetened with stevia leaves, with and without treatment. In general, no significant differences $(p>0.05)$ were observed between the contents of the two formulations. This can be justified because, although the ethanolic treatment of the leaves altered the contents of some componds, the contribution (proportion) of the stevia leaves in the composition of the cereal bar was small (1.8\%). Therefore, any significant variation in the compounds of the pretreated leaf was diluted within the highest levels observed in the cereal bars.

Dietary cereal bars without and with pre-treated stevia leafs had a moisture content of 15.0 and $14.6 \%$, respectively, within the limit established by Brazilian legislation, Resolution RDC $n^{\circ} 12$, of July 1978 (Brasil, 1978), of a maximum of 15\%, which provide satisfactory shelf life with long durability. This moisture content provides security against the growth of deteriorating microorganisms, since most fermentative bacteria, molds and yeasts require high moisture contents to proliferate. In addition, high humidity reduces crispness, which is the characteristic sensorial attribute of cereal bars and the loss of it is characterized by softening is a consumer rejection factor.

The low lipid levels observed may be justified by the formulations do not contain high fat ingredients, as opposed to other formulations that use margarine (Fonseca et al., 2011). The lipid levels observed in our formulations are considered satisfactory for the purpose of this study, since high fat diets are related to overweight, obesity, among other metabolic problems.

The total fiber contents found in the formulations of cereal bars made with stevia leaves with and without ethanolic treatment were $5.6 \%$ and $3.5 \%$, respectively. Although the stevia leaves used in both treatments originate the same lot and

Table 2. Mean results $(n=100)$ of the scores in the evaluation of sensory acceptance of pretreated and untreated stevia leaf cereal bar samples.

\begin{tabular}{lcc}
\hline \multicolumn{1}{c}{ Aspect evaluated } & Untreated leaf & Leaf with treatmen \\
\hline General aspect & $6.3^{\mathrm{a}} \pm 1.42$ & $6.5^{\mathrm{a}} \pm 1.51$ \\
Appearance & $6.0^{\mathrm{a}} \pm 1.40$ & $6.0^{\mathrm{a}} \pm 1.44$ \\
Texture & $6.5^{\mathrm{a}} \pm 1.39$ & $6.4^{\mathrm{a}} \pm 1.40$ \\
Aroma & $6.2^{\mathrm{a}} \pm 1.41$ & $6.3^{\mathrm{a}} \pm 1.41$ \\
Flavor & $5.9^{\mathrm{a}} \pm 1.84$ & $6.2^{\mathrm{a}} \pm 1.76$ \\
Intenção de compra & $3.1^{\mathrm{a}} \pm 0.93$ & $3.4^{\mathrm{a}} \pm 1.00$ \\
\hline
\end{tabular}

Values with different letters in the row are significantly different at $5 \%$ level by the ANOVA test. the same plant variety, we can not explain how the ethanolic treatment promoted this difference. However, it is most likely that the ethanolic treatment has dehydrated the leaves, which may have concentrated the fiber content (and also protein) by weight. Regarding the fiber contents, these are above average observed in the commercial cereal bars and those reported in the literature (Freitas \& Moretti, 2006).

Regarding the protein content, the formulations presented in this work had $12 \%$ and $11 \%$ (with and without treatment respectively), relatively higher and desirable contents, compared to similar products described in the literature, which presented $4.2 \%$ on average (Peuckert et al., 2010). As for the ash content, the cereal bars developed in this work had low levels in both formulations, however, these values are similar to those described by Deodato et al. (2015) who reported levels of $2 \%$ in cereal bars elaborated with facheiro flour.

The mean values of $\mathrm{pH}$ measured in the two formulations were 4.5 and may be justified by the lack of acidulants added to the formulation. Considering that $\mathrm{pH}$ below 4.0 becomes an environment unfavorable to the growth of mesophilic microorganisms, this result was important for the maintenance of shelf life of the product and maintenance of the nutraceutical properties of the product (Jay, 2005).

There was no significant difference between the averages for total titratable acidity $\left(0.4 \mathrm{~g}\right.$ citric acid $\left.\times 100 \mathrm{~g}^{-1}\right)$. Since organic acids present in foods influence the taste, odor, color, stability and maintenance of product quality, this result partly explains the similar assessments in the flavor and aroma aspects observed in the sensory analyzes for the two formulations. The determination of the total titratable acidity in foods is very important because it is through it we can obtain valuable data of the processing and the conservation of the foods (Cecchi, 2003).

The cereal bars presented a mean of $52 \mathrm{mg} \times 100 \mathrm{~g}^{-1}$ vitamin $\mathrm{C}$, a value similar to those reported by Peuckert et al. (2010) of $57 \mathrm{mg} \times 100 \mathrm{~g}^{-1}\left(14.3 \mathrm{mg} \times 25 \mathrm{~g}^{-1}\right)$ on cereal bar made with camu-camu fruit (Myrciaria dúbia), which compares with the vitamin $\mathrm{C}$ content of commercial cereal bars that presented, on average $36 \mathrm{mg} \times 100 \mathrm{~g}^{-1}\left(9 \mathrm{mg} \times 25 \mathrm{~g}^{-1}\right)$.

The results obtained for antioxidant activity and the contents of phenolic compounds present in cereal bars were statistically similar (Table 3), however, the concentrations of flavonoids were statistically different in the two formulations. It should be noted that any percentage of antioxidant concentration present in cereal bars represents a differential from the nutritional point of view, since Brazilian legislation does not require minimum antioxidant content in the final product (Brasil, 2003).

In this context, the cereal bars formulated in this study have nutritional properties beneficial to consumers, allowing the enrichment of their diet. The antioxidants obtained by food, slow down the aging process, combating or inactivating free radicals that are formed in spite of the natural defenses of the body, causing damages before being eliminated. A recent study (Barbosa et al., 2010) demonstrates that a healthy diet is essential to achieve the balance between antioxidants and the amount of free radicals produced by metabolism, since a healthy diet can provide carotenoids, lycopene, vitamin C, vitamin E, among others. 
Table 3. Centesimal composition and other phytochemical constituents of the cereal bar added Stevia leaf with and without ethanolic treatment.

\begin{tabular}{lrr}
\hline \multicolumn{1}{c}{ Analysis } & \multicolumn{1}{c}{$\begin{array}{c}\text { Untreated } \\
\text { leaf }\end{array}$} & $\begin{array}{c}\text { Leaf with } \\
\text { treatmen }\end{array}$ \\
\hline Valor energético & $83.3^{\mathrm{a}} \pm 0.39$ & $81.0^{\mathrm{b}} \pm 0.16$ \\
Proteins $\left(\mathrm{g} \times 100 \mathrm{~g}^{-1}\right)$ & $11.1^{\mathrm{a}} \pm 0.05$ & $12.2^{\mathrm{b}} \pm 0.13$ \\
Lipids $\left(\mathrm{g} \times 100 \mathrm{~g}^{-1}\right)$ & $2.7^{\mathrm{a}} \pm 0.15$ & $2.7^{\mathrm{a}} \pm 0.02$ \\
Ashes $\left(\mathrm{g} \times 100 \mathrm{~g}^{-1}\right)$ & $1.8^{\mathrm{a}} \pm 0.08$ & $2.1^{\mathrm{a}} \pm 0.02$ \\
Fibers $\left(\mathrm{g} \times 100 \mathrm{~g}^{-1}\right)$ & $3.5^{\mathrm{a}} \pm 0.09$ & $5.6^{\mathrm{b}} \pm 0.20$ \\
Moisture $\left(\mathrm{g} \times 100 \mathrm{~g}^{-1}\right)$ & $15.0^{\mathrm{a}} \pm 0.02$ & $14.6^{\mathrm{a}} \pm 0.05$ \\
Carboidrato & $66.1^{\mathrm{a}} \pm 0.10$ & $62.8^{\mathrm{b}} \pm 0.22$ \\
pH & $4.5^{\mathrm{a}} \pm 0.01$ & $4.6^{\mathrm{a}} \pm 0.01$ \\
Titratable acidity $\left(\mathrm{g}\right.$ citric acid $\left.\times 100 \mathrm{~g}^{-1}\right)$ & $0.4^{\mathrm{a}} \pm 0.00$ & $0.4^{\mathrm{a}} \pm 0.00$ \\
Vitamin C $\left(\mathrm{mg} \mathrm{ascorbic} \mathrm{acid} \times 100 \mathrm{~g}^{-1}\right)$ & $52.9^{\mathrm{a}} \pm 0.04$ & $52.9^{\mathrm{a}} \pm 0.05$ \\
Antioxidant activity $\left(\mu \mathrm{g} \times \mathrm{ET}^{-1}\right)^{*}$ & $0.9^{\mathrm{a}} \pm 0.73$ & $0.9^{\mathrm{a}} \pm 0.30$ \\
Phenolic compounds $\left(\mu \mathrm{g} \times \mathrm{EQ} \mathrm{g}^{-1}\right)^{* *}$ & $8.4^{\mathrm{a}} \pm 0.50$ & $8.0^{\mathrm{a}} \pm 0.16$ \\
Flavonoids $\left(\mathrm{mg} \times \mathrm{EQ} \mathrm{g}^{-1}\right)^{* * *}$ & $4.8^{\mathrm{a}} \pm 0.04$ & $6.2^{\mathrm{b}} \pm 0.57$ \\
\hline
\end{tabular}

Values with different letters in the column are significantly different at $5 \%$ level by the ANOVA test. ${ }^{*} \mu \mathrm{g} \mathrm{ET}=$ Trolox equivalents; ${ }^{* *} \mu \mathrm{g} \mathrm{EQ}=$ equivalent to quercetin; ${ }^{* * *} \mathrm{mg} \mathrm{EQ}=$ equivalent to quercetin.

\subsection{Microbiological evaluations}

The results of the microbiological analyzes for Salmonella, total yeast and mold counts, Bacillus cereus and coliforms at $45^{\circ} \mathrm{C}$ were lower than the reference values, which means that the samples are within the standards established by Brazilian legislation, the resolution RDC $\mathrm{n}^{\circ}$ 12, dated January 2, 2001 (Brasil, 2001), which allow the cereal bars to be used in the sensory analyzes, since they were microbiologically safe for human consumption, and are not a vehicle for microorganisms involved in food-borne diseases. These results also confirm that the hygiene and handling procedures of the cereal bars were performed properly, which ensured the microbiological safety of the product.

\subsection{Sensory analysis}

\section{Characterization of the panelists}

The sensory analysis was carried out at the State University of Maringá - PR, campus Umuarama, with untrained panelists composed by students, teachers, administrative, operational and laboratory technicians, aged between 15 and 55 . There was a predominance of the female gender, representing $66 \%$ of the panelists. Most of them were not adept at consuming cereal bars and diet foods. About 59\% of the panelists said they rarely consume; $18 \%$ consume daily; $17 \%$ consume once a week, and $6 \%$ of panelists never consumed.

\section{Acceptance of formulations regarding attributes general aspect,} appearance, consistency, aroma and taste

The two formualtions of cereal bar were equally accepted by the tasters in terms of the attributes: appearance, consistency, aroma, taste and overall aspect, as the Tukey test results showed no statistically significant difference $(\mathrm{p}>0.05)$ between the means of acceptance (Table 2; Figure S1 of the Supplementary Material). The averages lie between "I liked very much" and "liked

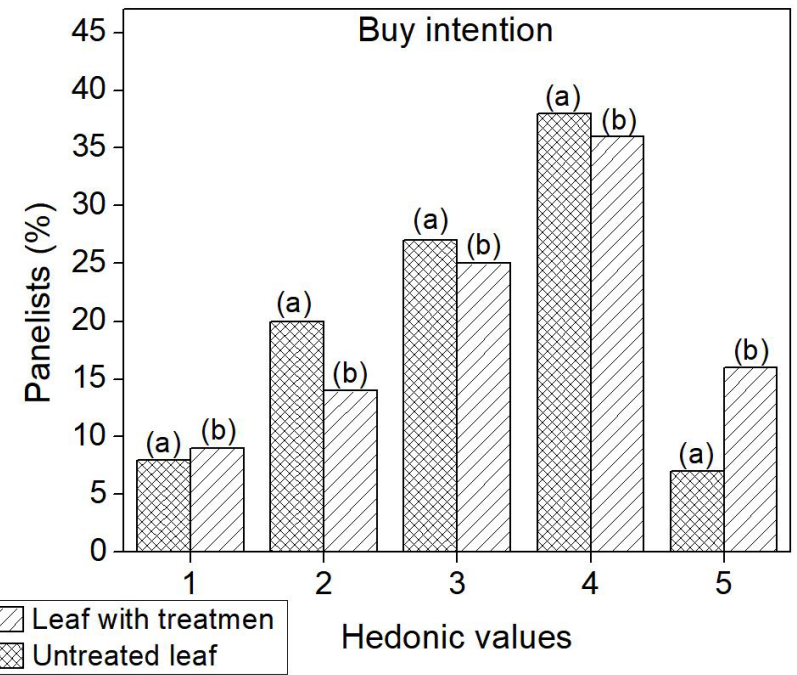

Figure 1. Average purchase intention of cereal bars sweetened with pre-treated and in natura stevia leaf. Values with different letters in the row are significantly different at $5 \%$ level by the ANOVA test.

moderately", meaning they showed good sensory acceptance. The two formulations using with stevia leaves with and without ethanolic pre-treatment, had a satisfactory incorporation potential without loss of sensorial attributes (Table 2), becoming a promising dietary product, since the market only provides diet cereal bars sweetened with synthetic sweeteners and, when natural, it is in the form of the isolated active principle, which have characteristics of have residual taste after swallowing.

When the level 5 range of the hedonic scale of purchase intent is evaluated (Figure 1), which is composed of panelists who would actually buy the product, the $\mathrm{F} 1$ formulation (made with pre-treated leaves) was better ranked regarding the formulation F2 (made with untreated leaves), demonstrating the good acceptance of this product among consumers of cereal bars.

\section{Conclusions}

It can be concluded from the results that the ethanolic pretreatment of stevia leaves slightly decreases the total glycosides contents, however, without altering the sensorial characteristics of sweet taste, as well as slightly decreasing the centesimal composition, with the exception of the total fibers. Two cereal bar formulations made with the same base, however, sweetened with stevia leaves in natura or pre-treated with ethanol, were successfully obtained. The sensory evaluation of these products showed that, among the regular consumers of cereal bars, the formulation sweetened with pre-treated leafs found more than twice the acceptance regarding to the formulation sweetened with the leaf in natura. This demonstrates that the use of stevia leaves pre-treated with ethanol may be a viable alternative as a natural sweetener for the development of food products.

\section{Acknowledgements}

The authors thank CNPq, CAPES (cod 001) and Fundação Araucária for the financial support and State University of Maringa (UEM) for the scholarship. 


\section{References}

Arnon, D. I. (1949). Copper enzymes in isolated chloroplasts: polyphenoloxidase in Beta vulgaris. Plant Physiology, 24(1), 1-15. http://dx.doi.org/10.1104/pp.24.1.1.

Barbosa, K. B. F., Costa, N. M. B., Alfenas, R. C. G., Paula, S. O., Minim, V. P. R., \& Bressan, J. (2010). Estresse oxidativo: conceito, implicações e fatores modulatórios. Revista de Nutrição, 23(4), 629-643. http:// dx.doi.org/10.1590/S1415-52732010000400013.

Brasil, Comissão Nacional de Normas e Padrões para Alimentos CNNPA. (1978, July 24). Normas Técnicas Especiais, do Estado de São Paulo, revistas pela CNNPA, relativas a alimentos (e bebidas), para efeito em todo território brasileiro (Resolução RDC no 12 , de 24 de julho de 1978). Diário Oficial [da] República Federativa do Brasil.

Brasil, Agência Nacional de Vigilância Sanitária - ANVISA. (2001, January 10). Regulamento técnico sobre os padrões microbiológicos para alimentos (Resolução RDC no 12, de 2 de janeiro de 2001). Diário Oficial [da] República Federativa do Brasil.

Brasil, Ministério da Saúde. (2003, December 26). Aprova regulamento técnico sobre rotulagem nutricional de alimentos embalados, tornando obrigatória a rotulagem nutricional (Resolução ANVS/ MS RDC no 360, de 23 de dezembro de 2003). Diário Oficial [da] República Federativa do Brasil.

Carvalho, M. W., Arriola, N. D. A., Pinto, S. S., Verruck, S., FritzenFreire, C. B., Prudêncio, E. S., \& Amboni, R. D. M. C. (2019). Stevia-fortified yoghurt: stability, antioxidant activity and in vitro digestion behavior. International Journal of Dairy Technology, 72(1), 57-64. http://dx.doi.org/10.1111/1471-0307.12559.

Cavalcanti, R. N., Santos, D. T., \& Meireles, M. A. A. (2011). Nonthermal stabilization mechanisms of anthocyanins in model and food systems: an overview. Food Research International, 44(2), 499-509. http://dx.doi.org/10.1016/j.foodres.2010.12.007.

Cecchi, H. M. (2003). Fundamentos teóricos e práticos em análises de alimentos (2. ed). Campinas: Unicamp.

Ciulu, M., Quirantes-Piné, R., Spano, N., Sanna, G., Borrás-Linares, I., \& Segura-Carretero, A. (2017). Evaluation of new extraction approaches to obtain phenolic compound-rich extracts from Stevia rebaudiana Bertoni leaves. Industrial Crops and Products, 108, 106112. http://dx.doi.org/10.1016/j.indcrop.2017.06.024.

Das, A., Golder, A. K., \& Das, C. (2015). Enhanced extraction of rebaudioside-A: experimental, response surface optimization and prediction using artificial neural network. Industrial Crops and Products, 65, 415-421. http://dx.doi.org/10.1016/j.indcrop.2014.11.006.

Deodato, J. N. V., Araújo, A. S., Severo, D. S., Silva, C. C. M., \& Alves, G. S. (2015). Produção e avaliação da qualidade das barras de cereais elaborada com farinha de facheiro. Revista Verde de Agroecologia e Desenvolvimento Sustentável, 10(3), 42-46. http://dx.doi.org/10.18378/ rvads.v10i3.3699.

Edwards, C. H., Rossi, M., Corpe, C. P., Butterworth, P. J., \& Ellis, P. R. (2016). The role of sugars and sweeteneers in food, diet and health: alternatives for the future. Trends in Food Science \& Technology, 56, 158-166. http://dx.doi.org/10.1016/j.tifs.2016.07.008.

Fonseca, R. S., Del Santo, V. R., Souza, G. B., \& Pereira, C. A. M. (2011). Elaboração de barra de cereais com casca de abacaxi. Archivos Latinoamericanos de Nutricion, 61(2), 216-223. PMid:22308949.

Formigoni, M., Milani, P. G., Silva Avíncola, A., Santos, V. J., Benossi, L., Dacome, A. S., Pilau, E. J., \& Costa, S. C. (2018). Stevia rebaudiana leaves pretreated with ethanol and characterization of the ethanolic extract by UPLC-HRMS. Food Chemistry, 241, 452-459. http://dx.doi. org/10.1016/j.foodchem.2017.09.022. PMid:28958553.
Freitas, D. G. C., \& Moretti, R. H. (2006). Caracterização e avaliação sensorial de barra de cereais funcional de alto teor protéico e vitamínico. Food Science and Technology, 26(2), 318-324. http:// dx.doi.org/10.1590/S0101-20612006000200014.

Gasmalla, M. A. A., Yang, R., Musa, A., Hua, X., \& Ye, F. (2017). Influence of sonication process parameters to the state of liquid concentration of extracted rebaudioside A from Stevia (Stevia rebaudiana Bertoni) leaves. Arabian Journal of Chemistry, 10(5), 726-731. http://dx.doi. org/10.1016/j.arabjc.2014.06.012.

Hegedüs, A., Pfeiffer, P., Papp, N., Abrankó, L., Blázovics, A., Pedryc, A., \& Stefanovits-Bányai, É. (2011). Accumulation of antioxidants in apricot fruit through ripening: characterization of a genotype with enhanced functional properties. Biological Research, 44(4), 339-344. http://dx.doi.org/10.4067/S0716-97602011000400004. PMid:22446596.

Honorato, T. C., Batista, E., Pires, T., \& Nascimento, K. O. (2013). Aditivos alimentares: aplicações e toxicologia. Revista Verde de Agroecologia e Desenvolvimento Sustentável, 8, 1-11. Retrieved from https://gvaa. com.br/revista/index.php/RVADS/article/viewFile/1950/2105

Instituto Adolf Lutz - IAL. (2004). Métodos físico-químicos para análises de alimentos (4. ed). São Paulo: IAL.

Jay, J. M. (2005). Microbiologia de alimentos (6. ed). Porto Alegre: Artmed.

Jentzer, J. B., Alignan, M., Vaca-Garcia, C., Rigal, C., \& Vilarem, G. (2015). Response surface methodology to optimise accelerated solvent extraction of steviol glycosides from Stevia rebaudiana Bertoni leaves. Food Chemistry, 166, 561-567. http://dx.doi.org/10.1016/j. foodchem.2014.06.078. PMid:25053094.

Kalicka, D., Znamirowka, A., Pawlos, M., Buniowska, M., \& Szajnar, K. (2019). hysical and sensory characteristics and probiotic survival in ice cream sweetened with various polyols. International Journal of Dairy Technology, 72, 456-465.

Kim, I. S., Yang, M., Lee, O., \& Kang, S. (2011). The antioxidant activity and the bioactive compound content of Stevia rebaudiana water extracts. LWT - Food Science and Technology, 44(5), 1328-1332. http://dx.doi.org/10.1016/j.lwt.2010.12.003.

Lemus-Mondaca, R., Vega-Gálvez, A., Zura-Bravo, L., \& Ah-Hen, K. (2012). Stevia rebaudiana Bertoni, souce of a high-potency natural sweetener: a comprehensive review on the biochemical, nutrition and functional aspects. Food Chemistry, 132(3), 1121-1132. http:// dx.doi.org/10.1016/j.foodchem.2011.11.140. PMid:29243591.

Lobete, M. M., Baka, M., Noriega, E., Jooken, E., Monballiu, A., de Beurme, S., Meesschaert, B., \& Van Impe, J. F. (2017). Stevia-based sweeteners as a promising alternative to table sugar: the effect on Listeria monocytogenes and Salmonella Typhimurium growth dynamics. International Journal of Food Microbiology, 245, 38-52. http://dx.doi.org/10.1016/j.ijfoodmicro.2017.01.008. PMid:28126702.

Martins, P. M., Thorat, B. N., Lanchote, A. D., \& Freitas, L. A. P. (2016). Green extraction of glycosides from Stevia rebaudiana (Bert.) with low solvent consumption: a desirability approach. Resource Efficient Technologies, 2(4), 247-253. http://dx.doi.org/10.1016/j. reffit.2016.11.007.

Miele, N. A., Cabisidan, E. K., Galiñanes Plaza, A., Masi, P., Cavella, S., \& Di Monaco, R. (2017). Carbohydrate sweetener reduction in beverags through the use of high potency sweeteners: trens and new perpectives from a sensory point od view. Trends in Food Science \& Technology, 64, 87-93. http://dx.doi.org/10.1016/j.tifs.2017.04.010.

Mooradian, A. D., Smith, M., \& Tokuda, M. (2017). The role of artificial and natural sweeteners in reducing the consumption of table sugar: a narrative review. Clinical Nutrition ESPEN, 18, 1-8. http://dx.doi. org/10.1016/j.clnesp.2017.01.004. PMid:29132732. 
Nowacka, M., Fijalkowska, A., Dadan, M., Rybak, K., Wiktor, A., \& Witrowa-Rajchert, D. (2018). Effect of ultrasound treatment during osmotic dehydration on bioactive compounds of cranberries. Ultrasonics, 83, 18-25. http://dx.doi.org/10.1016/j.ultras.2017.06.022. PMid:28693863.

Parlakpinar, H., Olmez, E., Acet, A., Ozturk, F., Tasdemir, S., Ates, B., Gul, M., \& Otlu, A. (2009). Beneficial effects of apricot-feeding on myocardial ischemia-reperfusion injury in rats. Food and Chemical Toxicology, 47(4), 802-808. http://dx.doi.org/10.1016/j.fct.2009.01.014. PMid:19271314.

Peuckert, Y. P., Vieira, V. B., Hecktheuer, L. H. R., Marques, C. T., \& Rosa, C. S. (2010). Caracterização e aceitabilidade de barras de cereais adicionadas de proteína texturizada de soja e camu-camu (Myrciaria dúbia). Alimentos e Nutrição, 21, 147-152. Retrieved from https://go.galegroup.com/ps/i.do? $\mathrm{p}=\mathrm{AONE} \& \mathrm{sw}=\mathrm{w} \& \mathrm{u}=$ goo glescholar\&v=2.1\&it=r\&id=GALE\%7CA246014859\&sid=google Scholar\&asid $=07003975$

Silva, N., Junqueira, V. C. A., \& Silveira, N F A. (2001). Manual de métodos de análise microbiológica de alimentos (2. ed). São Paulo: Livraria Varela.

Singleton, V. L., Orthofer, R., \& Lamuela-Raventós, R. M. (1999). Analysis of total phenols and other oxidation substrates and antioxidants by means of folin-ciocalteu reagent. Methods in Enzymology, 299, 152178. http://dx.doi.org/10.1016/S0076-6879(99)99017-1.
Srebernich, S. M., Meireles, F., \& Lourenço, G. (2011). Avaliação microbiológica de barras de cereais diet por meio de agente ligante hidrolisado e goma acácia. Revista de Ciências Médicas, 20(1-2), 5-13. Retrieved from http://periodicos.puc-campinas.edu.br/seer/ index.php/cienciasmedicas/article/view/819

Texeira, L. N., Stringheta, P. C., \& Oliveira, F. A. (2008). Comparação de métodos para quantificação de antocianainas. Revista Ceres, 55, 297-304. Retrieved from http://www.ceres.ufv.br/ojs/index.php/ ceres/article/view/3320

Wölwer-Rieck, U. (2012). The leaves of Stevia rebaudiana (Bertoni), their constituents and the analyses thereof: a review. Journal of Agricultural and Food Chemistry, 60(4), 886-895. http://dx.doi. org/10.1021/jf2044907. PMid:22250765.

Yildiz-Ozturk, E., Nalbantsoy, A., Tag, O., \& Yesil-Celiktas, O. (2015). A comparative study on extraction processes of Stevia rebaudiana leaves with emphasis on antioxidant, cytotoxic and nitric oxide inhibition activities. Industrial Crops and Products, 77, 961-971. http://dx.doi.org/10.1016/j.indcrop.2015.10.010.

Zhishen, J., Mengcheng, T., \& Jianming, W. (1999). The determination of flavonoid contentes in mulberry and their scavenging effects on superoxide radicals. Food Chemistry, 64(4), 555-559. http://dx.doi. org/10.1016/S0308-8146(98)00102-2. 


\section{Supplementary Material}

Supplementary material accompanies this paper.

Figure S1. Average of the attributes and purchase intention of the cereal bars made with stevia leaves with and without pre-treatment. The averages followed by equal letters on the same line do not differ significantly from each other $(p>0,05)$.

This material is available as part of the online article from http://www.scielo.br/cta 